\title{
Proses Pengambilan Keputusan Dalam Tindakan Keperawatan
}

\author{
Karima
}

\author{
$\underline{\text { Karimapiliang07@gmail.com }}$
}

\section{Lalar belakang}

Proses pengambilan keputusan dalam tindakan keperawatan merupakan komponen penting dalam proses keperawatan, sehingga dibutuhkan kemampuan perawatan karena keterbatasan pengetahuan dan kemampuan yang dimiliki perawat dapat menghambat perawat dalam mengambil keputusan mengenai perawatan yang akan diberikan kepada klien yang akan berakibat fatal terhadap klien. Penting bagi perawat untuk mampu mengambil keputusan dengan melibatkan pasien dan keluarga dalam asuhan keperawatannya sehingga proses keperawatan yang diberikan kepada klien ini diarahkan sebagai proses refleksi baik bagi perawat ataupun klien. Proses pengambilan keputusan dalam praktik klinik keperawatan dipahami sebagai serangkaian keputusan yang dibuat oleh perawat dalam interaksinya dengan klien mengenai jenis pengamatan yang akan dilakukan dalam situasi yang di alami klien (pengkajian keperawatan), perumusan diagnosa keperawatan, rencana tindakan keperawatan yang harus diambil, tindakan keperawatan yang akan diambil serta evaluasi. Perlu dipahami bahwa istilah keputusan klinis merupakan pilihan di antara alternatif yang ada sebagai upaya pemecahan masalah. Proses keperawatan hubungan perawat-klien sering rentan, karena perawat memiliki kekuatan lebih dari klien. Perawat memiliki pengaruh, akses, informasi, dan pengetahuan serta keterampilan khusus. Perawat memiliki kompetensi untuk mengembangkan hubungan terapeutik dan menetapkan batas-batas yang sesuai dengan kebutuhan klien. Hubungan perawat klien adalah dasar dari praktik keperawatan yang berfokus pada pasien (patient centered care). Keterlibatan pasien merupakan inti dari proses keperawatan, sehingga partisipasi pasien dalam proses keperawatan menjadi penting dalam penentuan kualitas dan efektifitas dalam pelayanan tindakan keperawatan. Dalam melakukan tindakan dalam pemberian asuhan keperawatan harus berdasarkan nilai-nilai dan etika yang dianut oleh klien dan nilai-nilai profesional asuhan keperawatan. Mengkombinasikan nilai profesional, etik dan nilai yang di anut klien akan meningkatkan pelayanan, identifikasi kebutuhan dan masalah keperawatan lebih sistematis sehingga meningkatkan pemahaman klien dalam pengambilan keputusan asuhannya. 


\section{Metode}

Metode yang digunakan dalam pembahasan ini yaitu menggunakan metode tersearch yang memberikan penjelasan dengan menggunakan analisis dari berbagai sumber seperti buku, jurnal, e-book dan membandingkan beberapa jurnal yang berhubungan dengan proses pengambilan keputusan dalam tindakan keperawatan.

\section{Hasil}

Hasil dari penelusuran ini adalah bahwa proses pengambilan keputusan merupakan sebuah refleksi dari perawat ataupun pasien. Membantu perawat dalam memecahkan masalah dan mengambil keputusan dengan baik dan hati-hati. Pengambilan keputusan dalam tindakan keperawatan harus ada interaksi antara perawat dengan klien, pengambilan keputusan dalam keperawatan dapat dilakukan dalam setiap proses keperawatan, tugas perawat pada saat proses pengambilan keputusan ini adalah sebagai fasilitator untuk memberikan fasilitas dan dukungan pada klien, pengambilan keputusan klinis dengan melibatkan klien akan meningkatkan tingkat kemandirian bagi klien, pengambilan keputusan klinis diperlukan kemampuan berpikir kritis bagi perawat. Yang terjadi di Indonesia pengambilan keputusan belum sepenuhnya dilakukan bersama antara perawat-klien. Perawat masih berperan sebagai pengambil keputusan tunggal. Sehingga dibutuhkan pemahaman lebih lanjut terkait dengan pengambilan keputusan klinis keperawatan dengan harapan peran perawat akan lebih terlihat nyata sebagai pemberi asuhan yang akan meningkatkan kepercayaan masyarakat terhadap profesi keperawatan. Dalam praktek sehari-hari perawat harus membuat keputusan diagnostik yang terkait dengan tugasnya dalam melakukan asuhan keperawatan. Perawat selain memberi asuhan keperawatan juga sering kali dituntut untuk dapat membantu dalam pemecahan masalah yang dihadapi oleh klien. Oleh karena itu perawat memerlukan pemikiran kritis, ketrampilan interpersonal dan berlandaskan etika keperawatan sehingga pasien dapat terbantu dalam mengambil keputusan. Partisipasi klien dalam mengambil keputusan juga sangat mempengaruhi. Dengan demikian, hubungan yang terjadi haruslah menguntungkan klien dan tidak memiliki efek yang negatif bagi klien. Kolaborasi perawat klien merupakan komponen utama dalam pemberian asuhan keperawatan, pengambilan keputusan merupakan bagian dari asuhan keperawatan, sehingga pengambilan keputusan dalam proses keperawatan harus melibatkan pasien dan keluarganya. Keterlibatan klien yang dimaksud dalam pengambilan keputusan ini adalah sebagai upaya pemberdayaan klien sehingga meningkatkan tingkat kemandirian klien. Tingkat kemandirian 
ini akan dicapai jika pasien dan keluarga mampu mengambil keputusan dengan baik dan tepat dalam memilih asuhan dan bantuan terkait kondisinya. Sehingga diperlukan peran aktif pasien dan keluarga dalam pengambilan keputusan klinis tersebut. Dalam beberapa penelitian disebutkan bahwa tugas perawat pada saat pengambilan proses pengambilan keputusan ini adalah sebagai fasilitator untuk memberikan fasilitas dan dukungan pada klien.

\section{Pembahasan}

Perawat melakukan pengambilan keputusan dalam setiap tindakan, sementara itu perawat juga merencanakan dan memberikan asuhan. Efektifitas dan ketepatan pengambilan keputusan membutuhkan kemahiran dalam mengumpulkan data dan keterampilan berpikir kritis. Berpikir kritis dalam keperawatan merupakan komponen yang sangat penting dari akuntabilitas profesional dan salah satu penentu kualitas asuhan keperawatan. Perawat yang memiliki kemampuan berpikir kritis akan menunjukkan sikap percaya diri, berpandangan konseptual, kreatif, fleksibel, rasa ingin tahu, berpikiran terbuka, tekun dan reflektif (Ingram, 2008).

Pengumpulan Data

Pengumpulan data merupakan tahap awal dari proses pengkajian. Perawat harus mengumpulkan data yang bersifat deskriptif, singkat, dan lengkap. Data deskriptif berasal dari persepsi klien tentang gejala, persepsi dan pengamatan keluarga, pengamatan perawat, atau laporan dari anggota tim perawatan kesehatan. Pengumpulan data dilakukan setiap kali berinteraksi dengan klien, keluarga dan sumber data pendukung. Pengumpulan data dilakukan melalui dua tipe, yaitu: pengkajian dasar (pengkajian screening) dan pengkajian terfokus.

Pengkajian dasar adalah pengkajian yang dilakukan ketika pertama kali klien masuk ke pelayanan kesehatan. Hal tersebut bertujuan untuk mengevaluasi status kesehatan dan mengidentifikasi fungsi pola kesehatan yang bermasalah (Gordon 1994; Craven dan Hirnle 2000). Pengkajian terfokus adalah pertanyaan atau observasi di mana perawat hanya mengambil hal yang perlu saja berdasarkan keluhan dan masalah utama yang dialami oleh klien (Carpenito dan Moyet 2000). Tujuannya untuk mengubah kondisi klien, yang kemudian dilanjutkan pada pengkajian yang lebih komprehensif. Selama pengkajian dasar atau screening, kadang-kadang kita melihat atau mendengar sesuatu yang menjadi masalah kemungkinan. Kita akan mengajukan pertanyaan tambahan yang merupakan pengkajian terfokus. Masalah dalam pengumpulan data; Ketidakmampuan mengelompokkan data sesuai dengan masalah, kehilangan data karena lupa mendokumentasikannya, data tidak relevan, duplikasi data, mispersepsi data, data tidak lengkap, interpretasi data tidak tepat. 
Sumber-sumber data bisa di dapat dari klien, keluarga dan orang terdekat, anggota tim perawatan kesehatan, catatan medis dan catatan lainnya. Metode pengumpulan data yang dilakukan yaitu; wawancara, observasi sistematis, pengkajian fisik, data laboratorium dan diagnosis.

Tipe data

Selama pengkajian, perawat mendapat dua tipe data, yaitu data subjektif dan objektif. Data subjektif adalah data yang didapat berdasarkan persepsi klien tentang masalah kesehatan mereka (Potter dan Perry). Pada klien anak atau bayi, data subjektif didapat dari orang tua atau sumber lainnya. Data objektif adalah data yang didapat dari pengamatan, observasi, dan pengukuran atau pemeriksaan fisik dengan beberapa metode (inspeksi, palpasi, auskultasi, perkusi)

\section{Rencana Kegiatan}

Perencanaan adalah kegiatan dalam keperawatan yang meliputi: meletakkan pusat tujuan pada klien, menetapkan hasil yang ingin dicapai, dan memilih intervensi keperawatan untuk mencapai tujuan ( Potter dan Perry 1997 ). Perencanaan keperawatan adalah metode pemberian perawatan langsung kepada klien. Pada pelayanan kesehatan, perencanaan dapat ditulis menggunakan komputer atau dengan formulir khusus. Perawat yang sudah berpengalaman tidak perlu membuat atau membaca lembaran perencanaan. Mereka hanya perlu membaca yang tidak rutin untuk prosedur diagnosis medis atau pembedahan. Jika perencanaan keperawatan diubah atau direvisi, maka perawat harus membaca ulang perencanaan tersebut. ( Carpenito dan Moyet 2007 ).

Proses pengambilan keputusan dalam keluarga

Proses pengambilan keputusan merupakan suatu proses rangkaian tindakan, perbuatan dalam proses pemikiran dengan memilih salah satu alternatif perilaku dari dua atau lebih alternatif untuk memecahkan masalah yang dihadapi dalam pencapaian suatu tujuan. Proses pengambilan keputusan dalam keluarga tentang kesehatan maternal merupakan salah satu indikator kekuasaan sosial yang dominan dalam keluarga dan didasari oleh kekuasaan yang dilegitimasi. Dalam suatu sistem keluarga ada kepercayaan pada seseorang yang mempunyai hak untuk mengambil keputusan terhadap yang lainnya, misalnya suami, istri, atau kakek/orang yang dituakan dalam keluarga. 
Pengambilan keputusan dalam keluarga tentang kesehatan maternal, faktor status kesehatan wanita, pengetahuan, sosio-ekonomi, pendidikan, budaya dan kepemilikan jaminan kesehatan atau askes sangat mempengaruhi pengambilan keputusan dalam keluarga.

Pengambilan keputusan dalam penggunaan layanan kesehatan sangat dipengaruhi oleh pemahaman individu akan karakteristik penyakit itu sendiri. Proses dimulai dari mengenali kondisi abnormal yang terjadi, mengetahui seberapa parah, dan mengetahui penyebab dari adanya kelainan yang dirasakan oleh individu lalu memutuskan untuk mencari perawatan. Sebelum memutuskan untuk mendapatkan pengobatan, individu perlu mengenali kondisi yang dihadapi seiring dengan dibutuhkannya perhatian yang lebih terhadap kondisi tersebut. Mengenali kondisi kesehatan dapat juga dibentuk oleh persepsi dan interpretasi sosiokultural. Misalnya kondisi yang pasti (hamil) dirasakan sebagai sesuatu yang alami dan tidak memerlukan perawatan medis tertentu.

Pengambilan keputusan dalam keluarga pada saat anggota keluarga mengalami komplikasi perinatal, berimplikasi pada status kesehatan maternal. Keterlambatan dalam pengambilan keputusan dapat mengakibatkan subjek kesehatan maternal yaitu perempuan, berada pada kondisi kesehatan yang beresiko bahkan dapat menyebabkan kematian baik itu kematian ibu maupun kematian janin. Pengambilan keputusan dalam keluarga yang berimplikasi pada status kesehatan maternal ini juga dipengaruhi oleh beberapa faktor. Faktor tersebut meliputi: pendidikan, pengetahuan keluarga akan komplikasi yang dialami, status perempuan dalam keluarga, sosio ekonomi keluarga, kepemilikan asuransi kesehatan, dan budaya yang berpengaruh pada keluarga.

Faktor-faktor tersebut di atas secara langsung berpengaruh pada status kesehatan maternal. Hasil peneliti menampakkan bahwa tidak optimalnya kesehatan maternal pada partisipan istri dimungkinkan karena kondisi sosio ekonomi keluarga yang dapat digolongkan pada kategori keluarga miskin. Faktor lain adalah rendahnya pendidikan maupun pengetahuan kesehatan maternal, terutama pengetahuan tentang komplikasi perinatal. Faktor budaya diyakini terkait dengan pemilihan penolong persalinan.

\section{Penutup}

Dalam proses pengambilan keputusan bahwa proses pengambilan keputusan merupakan sebuah refleksi dari perawat ataupun klien, pengambilan keputusan klinis keperawatan harus ada interaksi antara perawat-klien, pengambilan keputusan klinis keperawatan dapat dilakukan dalam setiap proses keperawatan, tugas perawat pada saat proses pengambilan keputusan ini 
adalah sebagai fasilitator untuk memberikan fasilitas dan dukungan pada klien, pengambilan keputusan klinis dengan melibatkan klien akan meningkatkan tingkat kemandirian bagi klien, pengambilan keputusan klinis diperlukan kemampuan berfikir kritis bagi perawat. Yang terjadi di Indonesia pengambilan keputusan belum sepenuhnya dilakukan bersama antara perawatklien. Perawat masih berperan sebagai pengambil keputusan tunggal. Sehingga dibutuhkan pemahaman lebih lanjut terkait dengan pengambilan keputusan klinis keperawatan dengan harapan peran perawat akan lebih terlihat nyata sebagai pemberi asuhan yang akan meningkatkan kepercayaan masyarakat terhadap profesi keperawatan. Peran keluarga pun sangat penting dalam pengambilan keputusan.

\section{Referensi}

Bandiyah, Siti. (2017). Ketrampilan Dasar Keperawatan. Yogyakarta: Nuha Medika

Hafifah, I., Fithriyah, N. (2018). Pengalaman Keluarga Dalam Pengambilan Keputusan Pada Pasien Kritis di Ruang ICU RSUD Ulin Banjarmasin. Dunia Keperawatan. 6 (1): 11-18

Heni. (2017). Berfikir Kritis Dalam Proses Keperawatan. Jurnal Keperawatan. 3(1), 26-29

Hartono. 2008. Konsep Dasar Keperawatan dengan Pemetaan Konsep. Pontianak : Salemba

Khairina,I., Malini,H., Huriana, E. 2020. Pengetahuan Dan Keterampilan Perawat Dalam Pengambilan Keputusan Klinis Triase. Jurnal LINK. 16(1) : 1-5

Kozier, B,. et al. (Ed.7). (2010). Buku ajar fundamental keperawatan : konsep, prosesdan praktik keperawatan (Eko Karyuni etal, Alih bahasa ). Jakarta: EGC

Muhith, A. 2015. Pendidikan Keperawatan Jiwa. Yogyakarta: ANDI

Rahayu, CD., Mulyani, S. (2020). Pengambilan Keputusan Klinis Perawat. Jurnal Ilmiah Kesehatan. 1-11

Sudono, B DS., Setya, D., Atiningtyas, R. (2017). Gambaran Kemampuan Berpikir Kritis Perawat Primer Dalam Pelaksanaan Asuhan Keperawatan Di RS Islam Surakarta. Jurnal Ilmu Keperawatan Indonesia. 10 (1) : 79-106.

Saifuddin, A.B. Buku panduan praktis pelayanan kesehatan maternal dan neonatal. Jakarta; Yayasan Bina Pustaka Sarwono Prawirohardjo, 2002.

Simamora, R. H. (2019). Menjadi perawat yang: CIH'HUY. Surakarta: Kekata Publisher. 
Simamora, R. H. (2005). Hubungan Persepsi Perawat Pelaksana Terhadap Penerapan Fungsi Pengorganisasian Yang Dilakukan Oleh Kepala Ruangan Dengan Kinerjanya Diruang Rawat Inap RSUD Koja Jakarta Utara (Doctoral dissertation, Tesis FIK UI, Tidak dipublikasikan). 